\title{
Klasik Dönem Osmanlı Tarih Yazarları ve Eserlerine Kısa Bir Bakış
}

\author{
Some Observations concerning the Classical Period of Ottoman \\ Historiographers and their Works
}

\section{Erdal TAŞBAŞ ${ }^{*}$}

Özet: Osmanlı Devleti'nin kuruluş yıllarındaki tarihçiliğe ilişkin bilgiler yetersiz olsa da sonraki dönemler hakkında oldukça geniş bir bilgi birikimi mevcuttur. Başlangıçta sade bir üslubun gözlemlendiği Osmanlı tarih yazımı giderek sanatsal amaçlarla kaleme alınan eserlerin yoğun olduğu İran tarihçiliğinden etkilenmiştir. Osmanlı tarih yazımında Farsça ve Arapça kullanımı yaygınlaşmış; ancak Türkçe'den bir kopuş da yaşanmamıştır. Osmanlı tarih yazıcılığında, Osmanlı hanedanını konu alan Tevârih-i Ali Osman'lar, fetihleri konu alan "Fetihnameler", "Gazavatnameler" ve "Zafernameler" bir hayli yaygındır. Mehmet Neşrî, Enverî, Şehdî, Aşıkpaşazade, Tursun Bey, İdris-i Bitlisî, Kemal Paşazade, Lütfi Paşa, Hoca Sadeddin, Selaniki ve Gelibolulu Mustafa Ali, Klasik Dönem'in önde gelen tarih yazarlarıdır. Her toplum ve uygarlıkta olduğu gibi Osmanlı Devleti'nde de tarihçilik anlayışı kendine özgü dinamiklere sahipti. Osmanlı'nın kuruluşundan yıkılışına kadar çeşitli dönemlerde kaleme alınan tarihi eserler devlet anlayışının ve mevcut koşulların niteliği hakkında ipuçları vermektedir. Osmanlı Devleti’nin en güçlü dönemi olarak bilinen ve Türk tarih anlatımında "Yükselme Dönemi" adıyla tanımlanan dönemdeki tarih yazımı da bu güce yaraşır bir hal almıştır. Yükselme Dönemi'nde kaleme alınan tarihi kronikler incelendiğinde, bu eserlerin devlet anlayışı ekseninde kaleme alındığını tespit edebilmek mümkündür.

Anahtar sözcükler: Tarihçilik, Klasik Dönem, Osmanlı kronikleri, resmi anlayış, tarih yazım dili

Abstract: Although knowledge of historiography during the early years of the Ottoman State is quite inadequate, there is a great deal of knowledge about the later periods. The Ottoman history writing practice, which was carried out in a simple style at the beginning, was later greatly influenced by Iranian history writing practices, in which art writings played an important role. Though Persian and Arabic became widespread in Ottoman History writing, it didn’t move too far away from Turkish. Tevârih-i Ali Osman's writings on the Ottoman Dynasties, Fetihnameler", "Gazavatnameler" and "Zafernameler" written on the conquests are very common examples of Ottoman historianship. Among eminent Ottoman historians are: Mehmet Neşrî, Enverî, Şehdî, Aşıkpaşazade, Tursun Beg, İdris-i Bitlisî, Kemal Paşazade, Lütfi Pasha, Hodja Sadeddin, Selaniki and Gelibolulu Mustafa Ali. As is the case in all communities and civilizations, historiography had its own dynamics within the Ottoman State. Works of history written during various periods from the rise to the fall of the Ottoman State provide indications about the Ottoman state's understanding and the characteristics of contemporary events. The understanding of history writing became very efficient during the period known in Turkish history as "The Period of Rising" when the Ottomans were the most powerful. When historical chronicles that were written during this period are examined, it can easily be seen that these works were written in accord with the Ottoman government's own understanding.

Keywords: Historicism, Classical historiographers, Ottoman chronicles, formal understanding, scribe the language of history

\footnotetext{
* Dr., Akdeniz Üniversitesi, Edebiyat Fakültesi, Tarih Bölümü, Antalya, etasbas@akdeniz.edu.tr
} 
Osmanlı Devleti'nin kuruluşundan 16. yüzyılın sonuna kadar olan ve 'Klasik Dönem' denilen üç asırlık zamana ait bilgiler, o dönemlerde yazılan tarihi kaynaklardan elde edilmektedir. Klasik Dönem'de tarz olarak çeşitlilik gösteren tarihi kaynaklar, devletin siyasi işleyişi ve kazanılan zaferlerle doğrudan ilişkiye sahiptir. Osmanlı Klasik Dönemi’nde verilen tarihi eserlerin niteliği ve sayısı padişahların iktidar süreçlerinde değişiklikler gösterir. Așağıda birçok tarihi eserin incelenmesinde de görüleceği gibi padişahın bu konudaki tutumu ve desteği bir tarihi eserin yazılmasında oldukça önemlidir.

Osmanlı Devleti'nin kurulmasından yaklaşık yüzyıl sonra başlayan Osmanlı tarih yazıcılığı bazı dönemlerde durgunluk yaşasa da devletin yıkılışına kadar kesintisiz olarak devam etmiştir. 17. yüzyılda vakanüvislik kurumunun oluşturulması ile Osmanlı tarih yazıcılığı resmi bir görev halini almıştır. Ancak 17. yüzyılda başlayan resmi tarihçilik öncesi Osmanlı Devleti'nin tarihi, kuruluş ve yükselme dönemlerinde yazılan kaynaklar aracılığıyla kayıt altına alınmıştır.

\section{Kuruluş Dönemi}

Doğu uygarlığında oldukça güçlü bir tarihçilik birikimi ve geleneği mevcuttur. Doğu-İslam uygarlıklarının mirasçısı olan Osmanlı Devleti'nde de tarih yazıcılığı mevcut geleneklerin üzerine kendine özgü ürünler vererek yüksek bir seviyeye ulaşmıştır. Güçlü bir tarih yazıcılığ anlayışı taşıyan Osmanlı tarihçiliği arkasında zengin bir birikim bırakmıştır (Coşkun, 1991, 43). Osmanlı Devleti'nin ilk yüzyıllarındaki tarihçilik ile ilgili bilgiler oldukça yetersizdir. Günümüze ulaşan tarih kaynaklarından anlaşıldığına göre, Osmanlı tarih yazıcılığı devletin kuruluşundan yaklaşık yüzyıl sonra başlamıştır. Bu gecikmenin nedeni belirsizliğini korumaktadır.

Sultan I. Murat'tan II. Murat'a kadarki zaman diliminde Farsça ve Arapça yazılmış olan eserler, egemen beyler adına Türkçe'ye çevrilmişti. Aynı dönemde kimi eserler de Osmanlı beyleri adına Türkçe'ye çevrilmişti. Bu tür kültürel çalışmaların ışığında Osmanlı tarih yazıcılığının 15. yüzyılın ilk yarısında başladığı söylenebilir (Enverî, 2003, XXIII-XXIV).

Türk tarihçiliğine dair İslam'a geçiş öncesi yazılmış ilk Türkçe eserler Karahanlılar Dönemi'ne aitti. Türkler Müslüman olduktan sonra Gazneliler ve Selçuklular zamanında bütün tarihi eserler Arapça ve Farsça olarak yazılmıştı. Osmanlılar zamanında ise Arapça ve Farsça'nın etkilerinin devam etmesine rağmen Türkçe de tarih yazıcıllğııda önemli bir yer tutuyordu (Kemal Paşazade, X, 1996, XIII). Osmanlı tarihçileri eserlerini, yöneticilerin başarılarının gelecekte hatırlanması amacıyla Arapça ya da Farsça yazıyorlardı. Ancak bazı padişahlar yine aynı amaçla Türkçe yazdırmayı yeğliyordu. Osmanlı padişahları ve diğer yöneticilerinin tarih yazma işinin uzun süreli faydasını kavraması, Osmanlıların kendilerine bakışındaki özgünlüğü ortaya koymaktaydı (Ersanlı Behar, 1996, 43).

XVI. yüzyıla kadar yazılmış yaklaşık 25 tarih eseri içinde Arapça ve Farsça olanların azınlıkta olduğu görülmektedir. Farsça kaleme alınan Şükrullah'ın Behcet'üt-Tevârîh'i ve İdris-i Bitlisî’nin Heşt Bihişt adlı eserleri vardır. Arapça olarak ise, Karamanî Kara Yakup b. İdris'in İsraku't-Tevârih ve Karamanî Mehmet Paşa'nın Tevârihu Selatini'l-Osmaniyye adlı eserleri mevcuttur. Bu durum Osmanlıların ilk dönemlerinde tarih yazıcılı̆̆ında Türkçenin daha yaygın kullanıldığını göstermektedir (Baş, 2005, 106).

Osmanlı tarih yazıcıllı̆ında, yaratılıştan başlayan genel tarih eserlerinin yanı sıra Osmanlı hanedanını konu alan Tevârih-i Ali Osman'lar, I. Selim'in saltanat yıllarını anlatan "Selimnameler", Kanuni dönemini anlatan "Süleymannameler" ile fetihleri konu alan "Fetihnameler", "Gazavatnameler" ve "Zafernameler" yaygind.

Bir devlet geleneği olarak adlandırılan Osmanlı tarih yazıcılığı, devletin tarihsel varlığ ve devlet-iktidar anlayışı konularında saraydan bağımsız olmayan Osmanlı tarihçisinin görüşlerini yansıtmaktaydı. Devleti yönetenlerin doğrudan etkisiyle ilişkide olan Osmanlı tarih yazıcılı̆̆ Osmanlı Devleti'nin ilk birkaç yüzyılında yöneticilerin başarıları ve hayat hikâyelerinden 
ibaretti. Tarih yazıcılı̆̆ına egemen olan akım padişahın yetkisinin sorgulanamadığı, imparatorluk ve başarıları etrafındaydı. Çünkü tarihçinin zaman ve yer anlayışı, imparatorluğu başka koşullar ve zaman dilimiyle karşılaştırma yaparak gözlemleme olanağından yoksundu (Ersanlı Behar, 1996, 41-42).

Oldukça geç zamanlara kadar Osmanlı tarih yazmaları birer kronik niteliğindeydi. Bu tarih yazıları, göçebe yaşam tarzının getirdiği koşullara bağlı olarak, gelişmemiş ve basit tasvirler şeklindeydi. Yazım amatörce ve basitti. Birbiriyle ilgisi olmayan olaylar destan ya da tarihi bir olgu olduğu göz önüne alınmadan birbirlerinden etkilenir. Bunları bir bütün olarak algılamak, birbirleriyle olan ilişkilerini tahlil etmek 15. yüzyılın sonlarına kadar göz ardı edilmiştir. Yerleşik yaşama tam olarak geçilip devlet kurumlarının oluşturulduğu dönemde ise yavaş yavaş tarih anlayışı ve anlatışı da değişecektir (Babinger, 2000, 7).

Osmanlı'da kaleme alınan ilk tarihi eserler birer destan niteliği taşımaktaydı. Bu konuda izlenen model İranlı yazar Firdevsi'nin başyapıtı olan Şahname'dir (Timur, 1994, 90). Osmanlı Devleti'nin kuruluşunu anlatan eserlerin büyük bir kısmı, geçmiş olayları yaşamış kişilerin anlattıklarının nesiller boyu kulaktan kulağa ulaşarak yazılmasıyla oluşmuştur. Bunlardan bilinen en önemli çalışma Yahşi Fakih Menakıbnamesi' dir ve yüzyıllarca birçok araştırmaya kaynak oluşturmuştur. 15. yüzyıl başlarında Yahşi Fakih tarafindan kaleme alındığı bilinen ve günümüze kadar ulaşamayan bu eser Osmanlı tarihine ilişkin ilk eserdir (Cengiz, 1989, 39).

Bir parçası olduğu Anadolu Selçuklularının Arapça ve Farsça ağılıklı dillerinin aksine Osmanlı'nın kullandığı dil oldukça sadeydi. Bu nedenle kuruluş döneminin tarihçiliği de okuyanların zevk almasına ve eğitimine hizmet eder nitelikteydi. Bu geleneği kuruluş döneminde devam ettiren Osmanlılar gazavatname şeklinde tarihi eserler yazmışlar ve yüksek sesle okunan bu eserlerle padişahların hem edebi zevkine hitap etmişler hem de gururunu okşamışlardır. 14. yüzyılın başındaki tarih yazımında, halkın çoğunluğunu oluşturan Türkmenlerin de etkisiyle Türkçe ön plana çıkmıştır. Osmanlı tarihi hakkında ilk Türkçe eser Ahmedî'nin "Dâsitân-ı Tevârih-i Mülûk-i Âl-i" adını taşıyan "İskendername"sidir (Başar, 2002, 409). Ahmedî’nin yazdığı bu manzum eser daha sonraki dönemlerde tarihi eser yazan bütün Osmanlı müelliflerine kaynak oluşturması bakımından önemlidir (Tekindağ, 1971, 657).

Osmanlı tarihçiliğinde çok önemli bir yer tutan gazavatname türünün ilk örneği de II. Murat zamanında verilmiştir. Bu türde çok sayıda eser daha sonraki yüzyıllarda kaleme alınacaktır (Enverî, 2003, XXIV). 14. yüzyılda Ahmedî'nin dışında Osmanlı tarihi hakkında önemli bilgiler veren diğer bir kaynak ise, tarihi takvimlerdir. Bu takvimlerde önemli olayların düzenli olarak kaydedildiği görülmektedir. Yine aynı yüzyılda diğer önemli bir kaynak da kahramanlıkları konu edinen menakıbnamelerdir (Aydın, 2002, 417-418). Menakıbnameler gerçekte olmuş bir olaya dayanır. Başlıca yazılma nedeni ideolojik ve siyasal bir formül ortaya koymaktır. Tarihi bir olgu olarak evrensel zamanları ve mekânları kapsadığı için dünya tarihinin siyasal oluşumlarında önemli bir yeri vardır (Ortayl1, 2000, 11).

Osmanlı Klasik Dönemi'nde tarih yazcılığında kullanılan edebi tarzlar dönemden döneme değişmekteydi. 14 ve 15. yüzyıllarda askeri zaferleri ve savaşları anlatan gazavatnameler yazılırken, 16 ve 17 . yüzyıllarda resmi tarih eserleri olan ve destansı tarzda kaleme alınan şehnameler ağırlıktaydı. Bunların yanı sıra kahramanlık hikâyelerini içeren menakıbnameler, gezi notlarını içeren seyahatnameler ve tarihten ders çıkarmak amacıyla yazılan nasihatnameler de Osmanlı tarih yazıcılığında önemli yer tutmaktaydı (Ersanlı Behar, 1996, 44).

Genel olarak Osmanlıların tarihçilik geleneğinin kökenlerine bakılacak olursa daha önceki Türk devletlerinin ve İç Asya efsanelerinin izleri görülür. Osmanlı tarih yazıcılığı başlangıçta sade bir dile sahip olmasına rağmen, zamanla İran tarihçiliğinin etkisine girmiştir. Sanatsal amaçlarla yazılmış olan İran tarih yazmaları Türkçe’ye çevrilmiş ve bu çeviri eserler Osmanlı tarih yazıcılığına model teşkil etmiştir. İran etkisinin yanı sıra ulemanın da katkılarıyla Arap 
tarihçiliği giderek etkili olmaya başlamıştır. Arap tarihçilik anlayışının Osmanlı tarihçiliğindeki öncüleri arasında Taşköprülüzade, Müneccimbaşı ve Kâtip Çelebi sayılabilir (Baş, 2005, 105). Osmanlı tarih yazıcılığında Arapça eserler ve yazarları hakkında daha ayrıntılı bilgiler aynı eserin 105-127. sayfalarında geniş bir şekilde incelenmektedir.

Selçuklulardan sonra tarih yazıcılığında Türkçe ön plana çıkmıştır. Özellikle XIV. yüzyıldan itibaren Farsça, Arapçanın yerini almaya başlarken Türkçe de Anadolu'da hakim dil olmaya başlamıştı (Tekindağ, 1971, 656). I. ve II. Murat dönemlerinde tarih yazıcıllğında Türkçe'nin üstünlüğü devam etmiştir. Daha önce Arapça ve Farsça kaleme alınmış olan eserlerin bu dönemde Türkçe'ye çevrilmesinden sonra Osmanlı tarih yazıcılığının kendine özgü biçimi ortaya çıkmıştır.

\section{Yükselme Dönemi}

Osmanlı tarih yazıcıllı̆̆, devletin kuruluşundan itibaren devletle ilişkili ve siyasetin gösterdiği gelişime bağlı olarak ortaya çıkmış ve devletin gelişimine paralel bir özellik kazanmıştır. Devlet siyasetiyle doğrudan ilişkili olan Osmanlı tarih yazıcılığı bu özelliğinden dolayı Osmanlı Devleti'nin dünya siyasetindeki konumundan etkilenmiştir (Coşkun, 1991, 43-44). Bu bağlamda Osmanlı tarih yazıcılığı, devletin dünya siyasetinde çok önemli bir yere sahip olduğu yükselme döneminde, dönemin koşullarına bağlı olarak büyük gelişmeler göstermiştir.

Osmanlı Devleti'nin yükselme döneminin zirvesi olan 16. yüzyıl öncesinde Neşrî ve Aşıkpaşazade gibi Osmanlı tarih yazarları, eserlerinde yalın bir dil kullanarak, vakayiname düzenine bağlı bir şekilde olayları aktarmışlardır. Buna karşılık iyi eğitimli yazarlar olan 16. yüzyıl tarihçileri, tarih yazıcılığını kibar edebiyat kapsamına giren bir alan haline getirmeye çalışmışlardır. Farsça'nın birikimli edebiyat-tarih geleneğinden yararlanan 16. yüzyıl Osmanlı tarih yazarları, düzyazı şeklindeki tarih yazımını bu dönemde olgunlaşan çok dilli ve karmaşık Türkçe edebiyat geleneğiyle bütünleştirmişlerdir (Fleischer, 2001, 244). Bununla beraber 16. yüzyılda olayları doğrudan aktaran düz tarih yazma geleneği de devam etmiştir.

II. Murat ve II. Mehmet dönemleri, kazanılan askeri ve siyasi zaferlerle dolu, devlet kurumlarının günün koşullarına göre düzenlendiği, yeni kurumların oluşturulmasının yanı sıra bilim, kültür ve sanat alanlarında da kayda değer ilerlemelerin yaşandığı bir dönem olmuştur. $\mathrm{Bu}$ padişahların aydınları korumaları ve eser vermeleri için teşvik etmeleri tarihçiye uygun bir ortam hazırlamış ve Osmanlı tarih yazıcılığının gelişmesine büyük katkılar sağlamıştır.

İlk müstakil Osmanlı ve dünya tarihleriyle, vekayinâme ve monografi yazımı İstanbul'un fethinden sonra başlamıştır (Özcan, 2003, 55). İstanbul'un alınmasıyla Osmanlı Devleti'nin saygınlığı dünya çapında artmış, "Fatih" unvanını alan II. Mehmet'in kahramanlığı üzerine methiyeler ve şiirler yazmak için adeta yarışan İranlı şairler akın akın İstanbul'a gelmiştir. Yeni Osmanlı başkentinin canlı kültürel yaşamı ve padişahın imparatorluğu pekiştirmek için hayata geçirdiği uygulamalar, toplumsal ve ideolojik gerilimler yaratmıştı. Bu ortam Osmanlı devlet yönetiminin tarihe ilgi duymasını ve tarihin siyasal faydalarının kavranmasını sağlamıştır (Fleischer, 2001, 246).

Osmanlı Devleti'nin kuruluşundan II. Mehmet'in tahtta çıkışına kadar geçen süreçte bilimsel esaslara dayalı bilimler özel bir yere sahip değildi. Buna karşılık dini bilimler Selçuklularda olduğu gibi aynen okutulmaktaydı. Ancak II. Mehmet'in bilimsel çalışmaları teşvik edici ve koruyucu yaklaşımlarından dolayı onun zamanında felsefi ve bilimsel düşünceler gelişmeye başlamıştı (Yurdaydın, 2002, 242). II. Mehmet zamanında Osmanlı Devleti kendi Rönesans'ını yaşamış, her alanda olduğu gibi tarih alanında da yeni yapılanmalara gidilmiştir. Bu devirde de eski eserlerin tercümesine devam edilmiş, yazılan eserlerin çoğu da Fatih Sultan Mehmet ve İstanbul'un Fethi'ni konu almıştır. Bu dönemde Tursun Bey'in kaleme aldığ Tarih-i Ebu'l-Feth ve Ebu'l-Hayr'ın Fetihnamesi ilk önemli eserlerdendir (Aydın, 2002, 417-418). Yine bu dönemde 
ortaya çıkan Osmanlı hanedanının kuruluşundan tarihi eserin yazıldı ̆̆ zamanına kadar gelen bir tarih yazıcılı̆̆ı metodu, uzun bir süre kullanılmıştır (Tekindağ, 1971, 657).

Diğer bir önemli eser olan Neşrî Tarihi, Osmanlı Devleti'nin kuruluşuna dair önemli bir kaynaktır. Neşrî'nin eseri öz Türkçe kelimeler içermekle birlikte yer yer katı Arapça ibareler ve kelimeler de mevcuttur. Mehmet Neşrî, kendi zamanının askeri ve siyasi olaylarını anlatan Neşrî Tarihi'nin giriş bölümünde Türkçe olarak yazılan Osmanlı öncesi kısa Türk tarihi, üzerinde önemle durulmayan bir konu olarak geçiştirilmiştir (Neşrî, 1983, 7). Evrensel bir tarih olarak yazılmış olan Cihannüma da Neşrî̀nin diğer önemli bir eseridir. Sekiz bölümden oluşan bu eser bir dünya tarihi niteliğindedir. Eserin, ancak Osmanlı Devleti kısmını içeren altıncı bölümü günümüze kadar ulaşmıştır (Babinger, 2000, 42). Günümüze ulaşan bu bölüm Oğuzlar, Selçuklular ve Karamanoğulları'yla ilgili özet bilgiler vererek başlar. 1288 yılında başlatılan Osmanlı tarihi 1485'teki Karaboğan Gazası'yla sona erer. Arkasından II. Beyazıt zamanında oluşturulan kurumlarla bu zamana kadarki ulema, şeyhler ve abdalları anlatan Neşrî, Sultana ithaf ettiği kaside ile eseri tamamlamıştır (Neşrî, 2008, VII).

Neşrî, tarih yazma işine hevesle ve gücünün yettiği ölçüde girdiğini, Osmanlı Devleti'nin kuruluşundan kendi zamanına kadar gelen olayları topladığını ifade etmektedir (Arıkan, 1991, 79). Neşrî'nin Cihannüma'yı yazarken daha önce yazılmış başka bir eserden kopya ettiğine yönelik görüşler de mevcuttur. Örneğin Babinger bu konuda Paul Wittek'in incelemelerini adres gösterir ve bazı örneklerle Neşrî’nin eserinin kopya olduğu şüphelerini kendisi de destekler (Babinger, 2000, 42).

Fatih Sultan Mehmet döneminin önemli tarihçilerinden olan Enverî de padişah adına Teferrücnâme adında tarihi bir eser kaleme almıştır. Enverî'nin 1465 yılında tamamlanan ve en önemli eseri olan Düstûrnâme, mesnevi tarzında yazılmış ve 3730 beyitten oluşan manzum bir eserdir. Enverî eserini kaleme alırken İslamî eserlerde takip edilen geleneklere de bağlı kalmıştır (Enverî, 2003, XXXIV). Düstûrnâme genel bir tarih eseri olarak zikredilmesine rağmen dünya tarihi olmaktan uzaktır. Eserde daha çok Asya devletleri üzerinde durulmaktadır. Bu bağlamda eserin dikkat çeken yanı, büyük kısmının Aydınoğulları Beyliği’ne özellikle Umur Bey’in faaliyetlerine ayrılmış olmasıdır (Özcan, 2003, 56).

II. Mehmet, Şehdî adında bir şairi sarayda şehname tarzında manzum bir Osmanlı tarihi yazmakla görevlendirmişti. Eserini planladığı şekilde bitiremeyip, ancak dört bin beytini yazabilen Şehdî, Osmanlı tarih yazıcılığında şehnameciliğin öncüsü sayılmaktadır. Resmi Osmanlı tarih yazıcılı̆̆ının ilk örneklerini oluşturan şehnamecilik, Kanuni Sultan Süleyman zamanında kurumlaşmış ve 17. yüzyılda vakanüvisliğin ortaya çıkmasına kadar devam etmiştir (Enverî, 2003, XXVI).

Osmanlı tarih yazıcılı̆̆ında önemli bir yere sahip olan Aşıkpaşazade, kaleme aldığı basit anonim hikâyeleri ve eserini kolay okunabilen duru bir Türkçe'yle yazmış, açık ve anlaşılır bir dil kullanmıştır. Eserde diyaloglara sıklıkla yer verilmiş ve cümleler kısa tutulmuştur (Aşıkpaşazade, 1992). Eserin bu özellikleri onun kalabalık topluluklarda okunmasını sağlamıştır. Eser, derviş gazilerinin görüşlerini yansıtmaktadır. Neşrî'nin de kaynak olarak kullandığı bu eserin kapsadığ (Arıkan, 1991, 77). Aşıkpaşazade tarih yazmaktaki asıl görevinin Yahşi Fakih Menakıbnamesi'nden yola çıkarak Osmanlı Devleti tarihini derlemek olduğunu belirtmektedir.

II. Mehmet dönemi olayları hakkında en geniş bilgiyi bulabileceğimiz eser olan Tarih-i Ebu'l-Feth'in yazarı Tursun Bey'in hayatı hakkında fazla bir bilgi yoktur. Ancak yazdığ eserinin önemi nedeniyle büyük Osmanlı tarihçileri arasında yer alan Tursun Bey hakkındaki tek mevcut bilgi kendi anlatımına dayanmaktadır. Çünkü Tursun Bey eserinin önsöz kısmında kendisine ait bilgiler vermektedir. 
II. Mehmet'in siyasi kuramcısı olarak görülen Tursun Bey, örfi ve şer'i hukukun birlikte işleyişini güçler ayrılığı ilkesi açısından değerlendirmek istemiştir. Tursun Bey, padişah-uyruk ilişkileri konusunda Farâbi ve Nasreddin Tûsi'den etkilenmiștir. Ona göre padişah, bütün tebaayı becerilerine göre hakkına razı etmek ve başkalarının haklarına gasp etmesini engellemek için vardır ve bunu yaparken de tanrının iznine tabiidir (Sencer, 2002, 67). Osmanlı devlet adamı ve tarihçisi olan Tursun Bey eserinde, toplum üyeleri arasındaki uyumun, her bireyin toplum içerisindeki yeteneğine göre belirlenmiş olan yerini korumasını amaç edinen devlet politikasıyla mümkün olacağını özellikle vurgulamaktadır. Ona göre sosyal düzenin sağlayıcısı ve araç olarak devlet yönetimi, iki türlü yaptırım gücüne sahiptir. Bunlar padişahın otoritesi ve hâkimiyetiyle şeriattır (İnalcık, 1990, 30). Fatih dönemi açısından en önemli eser olan Tarih-i Ebu'l-Feth'e göre şeriat hukukunun yanı sıra örfi hukukun da varlığı gereklidir (Arıkan, 1991, 77-78).

Tursun Bey'in felsefi bir yaklaşımla kaleme aldığı eseri Tarih-i Ebu'l-Feth (Fatih'in Tarihi) anlamına gelmektedir ve Türkçe'dir. Buna rağmen anlatım dili Farsça öğeleri çağrıştırmaktadır. Tursun Bey'in eserindeki dil ve üslup yapısı aynı dönemde yazılan Aşıkpaşazade, Oruç ve Neşrî'den farklıdır. Diğer eserlerde süssüz ve net bir anlatım hakimken Tursun Bey'in eserinde Arapça ve Farsça yapılara daha uygun olan uzun cümleler, bol bol sıfat, benzetmeler, mecazi ifadeler ve mitolojik unsurlar fazla kullanılmıştır (Tursun Bey, 1977, XXXI). Tursun Bey eserinde bazı olayları uzun uzun kaleme almış, bazı olayları da kısa geçmiştir. Örneğin; Fatih'in ilk tahta çıkışından Sadrazam Mahmud Paşa'nın ilk sadaretinden azledilmesine kadar geçen olaylar çok geniş verilmiştir. Fakat bu tarihten sonraki olaylar kısa olarak kaleme alınmıştır. Cem Sultan olayına ise hiçbir şekilde yer verilmemiştir (Tekindağ, 1977, 123).

II. Beyazıt dönemine gelindiğinde tarih yazıcılığının hem halk nezdinde hem de sarayda olumlu sonuçları görülmeye başlamıştı. Sultan, çağın en saygın hükümdarı görünümüyle öne çıkılması ve II. Mehmet'in zor koşullara rağmen iyi bir duruma getirdiği devlete kültürel bir meşruiyet kazandırılması gerektiğine inanmaktaydı (Fleischer, 2001, 247).

II. Beyazıt döneminde Osmanlı tarihi hakkında oldukça fazla eser kaleme alınmıştı. Hem II. Mehmet dönemindeki gelişmelerin ürünü olarak hem de II. Beyazıt'ın ilim adamlarını koruyup, onları tarih yazmaya teşvik eden politikaları nedeniyle bu dönemde tarih yazıcılığı çok gelişmiştir. II. Beyazıt döneminde yazılan genel Osmanlı tarihlerinin yanı sıra, sadece bir padişahın dönemini kapsayan eserler de yazılmıştır. Bu tür eserlerin ilk örneğini Tursun Bey yazmıştır. II. Beyazıt döneminde çok sayıda eser yazılmasının yanı sıra olayları ayrıntılı olarak anlatan eserler de kaleme alınmıştır. Bu dönemdeki yı̆̆ılmanın temel sebeplerinden birisi, yukarda da belirtildiği gibi, sultanın ilim adamlarını himaye etmesi ve onları teşvik etmesidir. Osmanlı tarih yazıcılı̆̆ında daha hacimli eserlerin ise II. Beyazıt döneminden sonra yazıldığı görülür. Ancak bunda II. Beyazıt'ın attığı temeller çok önemlidir. Çünkü O, İdris-i Bitlisî ve Kemal Paşazade gibi dönemin önemli âlimlerini, İran'da yazılan büyük tarihler gibi, Osmanlı tarihi yazmakla görevlendirmiştir.

İbn-i Kemal veya Kemal Paşazade diye bilinen Şemsü’d-dîn Ahmed b. Süleyman (İbn-i Kemal, 1970, 1), padişahın tarih yazmakla görevlendirdiği önemli tarihçilerden biridir. II. Beyazıt'ın isteği üzerine bir tarih yazmaya başlayan Kemal Paşazade, Osman Gazi'den başlamak üzere her padişah için ayrı bir defter olmak üzere bir Osmanlı tarihi kaleme almıştır. Eserini iki parti halinde padişaha sunan Kemal Paşazade'nin Tevârih-i Al-i Osman adlı eserinin birinci bölümünü oluşturan orijinal nüsha günümüze kadar ulaşmamıştır. Kanuni'nin, Kemal Paşazade'yi eserinin ikinci bölümlerini yazması için görevlendirmesiyle yazar, II. Beyazıt ve I. Selim ile Kanuni'nin saltanatının ilk yedi yılını kapsayan üç defter daha yazmıştır. Böylece Kemal Paşazade'nin eseri 10 deftere tamamlanmıştır (Kemal Paşazade, X, 1996, XXII-XXIII). Kemal Paşazade eserini oluşturmak için daha önceki kroniklerden alıntı yaparken farklı bir 
yöntem kullanmıştır. Önceki eserleri karşılaştırmış, eserlerde geçen kimi rivayetlerin kendine mâkul gelenlerini eserine almıştır. Daha önceki eserlerden olduğu gibi alıntı yapmaması, aralarında senteze gitmesi onun eserini eski bir kroniğin kopyası olmaktan kurtarmıştır (İbn-i Kemal, I, 1970, 25). Kemal Paşazade eserinin birinci defterini yazarken Reşidüddin, Ruhi Çelebi, Tevkı 'î Mehmed Paşa ve Neşri'nin eserleriyle bir Anonim Tevârih-i Âl-i Osman ve tarih takvimlerinden yararlanmıştır. Özellikle Neşrî’nin Cihannüma'sı ve Anonim Tevârih-i Âl-i Osman'dan yaptığı alıntılar diğerlerine göre ziyadedir (İbn-i Kemal, I, 1970, 24).

Edirne'deki Sultan Beyazıt Medresesi'nin hocalarından olan ve Kanuni zamanında Zembilli Ali Efendi'den sonra 1526 yılında şeyhülislamlığa getirilen Kemal Paşazade eserinde Şiilerin öldürülmesinin caiz, mallarının helal olduğunu ve onlarla yapılacak savaşın diğer dinlere mensup topluluklarla yapılanlar gibi cihad sayılacağını ileri sürmüştür. Molla Kaabz'ın, Hz. İsa'nın Hz. Muhammet'ten daha üstün olduğunu savunması nedeniyle Divan'da yargılanması sırasında Osmanlı ulemasının yetersiz kalmasıyla Kemal Paşazade onun görüşlerini çürütmek maksadıyla üç tane risale yazmıştır. Bu risalelerden birincisi, Hz. Muhammet'in diğer peygamberlerden üstün olduğunu kanıtlamaya yönelikken ikincisi, Molla Kaabz'ın iddialarını çürütmeye yönelikti. Üçüncüsü ise din dışılığı ve din karşıtlığının tarihi seyri ve çeşitleri üzerineydi (Yurdaydın, 2002, 216).

Tarihi bir eser yazmak üzere II. Beyazıt'tan emir alan Kemal Paşazade, bu emri yerine getirmek için imparatorluğun değişik yerlerine gidiyor ve oralarda kalıyordu. Bu arada hukuk, tarih ve şiir gibi konularda da dersler alıyordu. Kemal Paşazade'nin edebi kişiliği çok gelişmiş olduğu için çeşitli bilim dallarında yazdığı çok sayıda risalesi de mevcuttu. Ancak Kemal Paşazade'yi Osmanlı tarih yazıcılı̆̆ 1 alanında önemli kılan bu çalışmalarından çok, yazmış olduğu on ciltlik Osmanlı Tarihi'dir (Babinger, 2000, 69). Kemal Paşazade, eserinde Osmanlı tarihini Türk tarihinin akışı içinde ve bir bütün olarak ele almış, Osmanlı Devleti’nin yükselme nedenlerini ortaya koymuştur (Arıkan, 1991, 78).

Sufilerin vahdet-i vücud görüşlerinin karşısında önemli mücadeleler veren Kemal Paşazade'nin bu konularda verdiği birçok fetva mevcuttur. Kaleme aldığ fetvalarıyla Kemal Paşazade, İran'da yükselen ve Osmanlı Devleti'ne zarar vermeye başlayan Şiilik propagandasının etkisiyle sarsıntı geçiren Osmanlı toplumunun bu durumunda ehl-i sünnet düşüncesini bütün gücüyle savunmuş ve bu yönde çalışmalar yapmıştır.

II. Beyazıt'ın isteği üzerine tarih yazan diğer bir Osmanlı tarihçisi de İdris-i Bitlisî’dir. Farsça bir eser kaleme alan Bitlisî, Heşt-Bihişt adını verdiği eseriyle Osmanlı tarih yazıcılığında bir çığır açmıştır. İdris-i Bitlisî, İran dil, edebiyat ve tarih yazıcılığının bütün özelliklerini ve inceliklerini kullanarak Osmanlı tarihinin de bu yöntemlerle yazılabileceğini kanıtlamaya çalışmıştır (Arıkan, 1991, 78). Dili nedeniyle kendinden sonrakiler tarafından pek anlaşılamamıştır. Padişah II. Beyazıt'ın tarih yazmakla görevlendirdiği bu iki tarihçiden Kemal Paşazade tarihini Türkçe yazarken, İdris-i Bitlisî de Farsça'yı tercih etmiştir. 1502 yılında bu göreve başlayan İdris-i Bitlisî eserini iki buçuk yılda tamamlamış ve eserine sekiz cennet anlamına gelen HeştBihişt adını vermiş̧tir. Eserde Osmanlı tarihi, Osman Bey'den başlayarak II. Beyazıt'ın son yıllarına kadar geçen olaylarla anlatılmıştır (Uğur, 1991, 9).

II. Beyazıt döneminde Osmanlı tarih yazıcılığı önceki dönemin tarih yazıcılığı birikiminin de sağladığı olanaklarla çok daha parlak bir dönem yaşamıştır. Bu dönemde Osmanlı tarihi açısından çok değerli tarihi eserler kaleme alınmış, padişahın bilinçli ve samimi bir şekilde destekte bulunması da bunda oldukça etkili olmuştur.II. Beyazıt döneminden sonra sadece bir padişah döneminin tarihini ya da bir savaşı anlatan tarihler yazılmaya başlanmış, Selimnâme ve Süleymannâme gibi tarih eserleri kaleme alınmıştır. Daha sonra Şehnâme türünde minyatürlü eserler kaleme alınmış, bunları 17. yüzyılda yazılmaya başlanan Vakanüvis tarihleri izlemiştir (Başar, 2002, 413-414). 
Osmanlı Devleti'nde 16. yüzyıldan itibaren dini taassup giderek daha etkili olmaya başlamıştı. Bu gelişmenin en önemli nedeni, İran'da Şiiliğe dayalı bir devletin kurulması ve bu devletin başındaki Şah İsmail'in Anadolu Türkmenleri üzerinde etkili olmaya başlamasının Osmanlı Devleti için giderek büyük bir tehlike halini almasıdır. Bu gelişmeler karşısında Osmanlı Devleti de kendi tavrını ortaya koyacaktır. Yavuz Selim her şeyden önce Osmanlı toplumunu İran'a karşı hazırlama gereği duymuş ve zamanının önemli bilginlerini harekete geçirerek, onlardan Şiiliğgin hak mezhep olmadığını Osmanlı tebaasına anlatmalarını istemiştir (Yurdaydın, 2002, 215).

II. Beyazıt'tan sonraki padişahın tarih yazımıyla ilgili kayda değer görevlendirmeler yapmadığı görülmektedir. Ancak Kanuni tarih yazımına önem vermiş ve bunun için de sarayda şehnamecilik makamını oluşturmuştu. Sarayın verdiği görevi yapan şehnamecinin işi Farsça manzum ve methiye tarzında Osmanlı tarihi yazmaktı. 16. yüzyılın sonuna kadar bu anlayış devam etmiş, bu dönemde yazılan tarihler ve saray edebiyatı genel olarak Farsça'daki edebi biçimlere bağlı kalmıştı (Fleischer, 2001, 247).

Yavuz Sultan Selim zamanında Misır ve Suriye'nin fethedilmesinden sonra "sene sene yazan klsa ve münakkah" Arap tarihçiliğinin artık ağır ağır Osmanlı tarih yazıcılığında etkisini göstermeye başladığı görülür (Tekindağ, 1971, 659). Osmanlı Devleti'nde bu dönemden itibaren yükselen dini taassup söz konusudur ve yükselmesinin önemli nedenlerinden birisi de I. Selim'le birlikte Osmanlı sultanlarının halifelik sıfatını kazanmış olmasıdır. Ancak Mısır'ın alınmasıyla, günümüzde bile tartışılan bir konu olan halifeliğin Osmanlı sultanına geçmesi, eserinden anlaşıldığına göre Lütfi Paşa'nın zamanında da bir tartışma konusuydu. Lütfi Paşa 1554 yılında yazmış olduğu "Halas'l-Ümme fî marifeti'l-Eimme" adlı eserinde halifelik tartışmalarını peygamber hadisleri gibi çeşitli kanıtlara dayanarak açıklığa kavuşturmaya çalışmış ve Osmanlı sultanlarının halifeliğini savunmuştur (Yurdaydın, 2002, 220).

Lütfi Paşa'nın Tevârih-i Âl-i Osman adını taşıyan eseri 1553 yılına kadarki olayları anlatmaktadır. Eser Kanuni de dâhil olmak üzere o zamana kadarki Osmanlı padişahlarının saltanat yıllarında yaşanan olayları dönemlere ayırarak, kronolojik bir sırayla kaleme almıştır. Lütfi Paşa, eserinin giriş kısmında yazdığı tarihin bir kısmını kendi çabalarıyla bir kısmını da daha önceki kroniklerden seçtiklerini özetleyerek oluşturduğunu belirtse de eserinin kendi yaşadığ zamanı anlatan kısım başlı başına bir kaynak oluşturacak niteliktedir (Lütfi Paşa, 1341). Ancak Lütfi Paşa'nın eserini yazarken kendi dönemi dışındaki kısımları, daha önce yazılan Osmanlı tarihlerinden kopya ettiği belirtilmektedir (Babinger, 2000, 90). Lütfi Paşa'nın en önemli eseri bir siyasetname özelliği taşıyan Asafname'dir. Lütfi Paşa dört bölümden oluşan bu eserinde, sırasıyla sadrazamın nitelikleri, sultan ve halkla olan ilişkileri, savaşlar, hazine ve reaya ile ilgili konularda yapılması ya da olması gerekenler konusundaki düşüncelerini kaleme almıştır. Çeşitli yönetsel görevlerde bulunan Lütfi Paşa, kısa bir süre sadrazamlık da yapmış ve eserini kaleme alırken bu mevkilerde bulunmanın sağladığı avantajları da kullanmıştır (Yurdaydın, 2002, 222).

Dönemin diğer önemli bir tarihçisi Tâcü't-Tevârih adlı meşhur eserin yazarı Hoca Sadeddin'dir. Halk arasında Hoca Tarihi diye ünlenen bu eser ciddi araştırmalar sonucunda meydana getirilmiştir. Selaniki ve Naima'nın yazmış oldukları meşhur tarihi eserler Tâcü'tTevârih'i izleyen ve tamamlayan tarihler olarak bilinmekte, bu haliyle eser Osmanlı kuruluş devrinin temel kaynaklarından biri olarak görülmektedir (Hoca Sadettin Efendi, I, 1992, IX).

Hoca Sadeddin meşhur eserinin beşinci ve son cildinde "Hatime" başlı̆g 1 altında zamanının edebiyat ve kültür alanlarında tanınmış kişilerini anlatmıştır. Bu bölümde medreselerin doğuşları, bilimsel gelişmeler, üst düzey yöneticiler, bilim adamları ve çağın eğitimcileriyle şeyh ve tasavvufçular arasındaki tartışmalar ve anlaşmazlıkları anlatan eser, Osmanlı bilim tarihine de 1şık tutucu niteliktedir. Hoca Sadeddin bu bölümü oluştururken üç yüz yıllık bir zaman diliminde bilim ve düşün adamlarını bir arada sunarken Osmanlı bilim ve kültür yaşamının nelerden esin- 
lendiği ve hangi aşamalardan geçtiğini gözler önüne sermektedir (Hoca Sadettin Efendi, I, 1992).

Tacü't-Tevârih'in ilk cildi Osmanlı Devleti'nin kuruluşundan Yıldırım Beyazıt'ın ölümüne kadarki ve ikinci cilt ise Fetret Devri'nden İstanbul'un alınmasına kadarki olayları içermektedir. Üçüncü cilt II. Mehmet ve II. Beyazıt devri olaylarını, dördüncü cilt ise, I. Selim dönemini anlatmaktadır (Hoca Sadettin Efendi, I, 1992, XII). Beşinci cilt ise, yukarıda da değinildiği gibi "Hatime" bölümünden oluşmaktadır. Bu eser Osmanlı tarihi için oldukça önemli ve daima başvurulan bir kaynaktır. Osmanlı Devleti'nin kuruluşundan I. Selim'in ölümüne kadar geçen olayları süslü bir şekilde anlatan eser, eski eserlerden birçok alıntıyı da içermektedir. Ayrıca Hoca Sadeddin babasından dinlediklerine dayanarak bir de Selimname yazmıştır. Bu Selimname, I. Selim'in saltanatı ve yaşamı hakkında bir dizi fikradan oluşmaktadır ve bir tarihi eser olmaktan uzaktır (Babinger, 2000, 138-139).

Klasik Dönem Osmanlı tarih yazıcıllğında çok önemli bir yere sahip olan diğer bir tarihçi de Gelibolulu Mustafa Ali'dir. Osmanlı düşünce hayatının en önemli kişilerinden birisi olan Gelibolulu Mustafa Ali’nin çoğu tarihî olmak üzere otuz kadar eseri vardır. Eserlerinde mutlak doğrucu arayışları ve inandırıcılık konuları dikkate alındığında çağdaşı olan birçok yazardan ayrilır.

Gelibolulu Mustafa Ali çok yönlü bir yazar olarak birbirinden farklı alanlarda birçok eser yazmıştır. Son ve en önemli eseri olan Künhü'l-Ahbar'da yazdığı eserlerin sayısını elli olarak belirtmiş olmasına karşın bunların tamamı günümüze ulaşmamıştır (İsen, 1988, 11). Gelibolulu Mustafa Ali'nin Künhü'l-Ahbar adlı eseri klasik Osmanlı tarih anlayışı ile yazılmasına rağmen diğer tarihi eserlerden ayrılmaktadır. Çünkü her şeyden önce kendi devrinin olaylarını ve yöneticilerini değerlendirmesi bakımından farklı bir yaklaşım sergiler. Ayrıca Gelibolulu Mustafa Ali, Osmanlı Devleti'ni anlattı̆̆ bölümün son kısmında, Yıldırım Beyazıt ve II. Selim dönemleri arasında yetişen devlet adamları, din adamları, bilginler ve sanatçılar hakkında biyografik bilgiler vermiş ve orijinal nitelikte yargılamalarda bulunmuştur (Şeker, 1997, 25).

Gelibolulu Mustafa Ali'nin kaleme aldığı ve genel dünya tarihi niteliğinde bir eser olan Künhü’l-Ahbar, 16. yüzyıl Osmanlı tarih yazılığı açısından oldukça önemli bir eserdir. Dört bölümden oluşan eserin ilk bölümü dünyanın yaradılışı, coğrafi bilgiler ve peygamber menk1belerinden, ikinci bölümü Arap tarihinden, üçüncü bölümü Türklerden, Tatarlardan ve Beyliklerden, son bölümü ise Osmanlı hanedan tarihinden ve Rum memleketlerinden bahsetmektedir (Babinger, 2000, 143). Eserin asıl önemli bölümü 300 yıllık Osmanlı tarihini anlatan dördüncü bölümdür. Gelibolulu Mustafa Ali bu bölümü ikiye ayırmış, birinci kısımda Osmanlı Devleti'nin kuruluşundan Yavuz Sultan Selim zamanına kadar olan dönemi anlatmıştır. İkinci kısım ise Kanuni Sultan Süleyman devrinden III. Mehmet devri başlarına kadar gelmektedir (İsen, 1988, 12).

Gelibolulu Mustafa Ali eserinin önsözünde tarih, tarihin faydaları ve tarihçiler hakkındaki fikirlerini de aktarmıştır. Gelibolulu Mustafa Ali burada tarihin tanımını yapmış ve tanıma ibret alınması gerekliliğini eklemiştir. Tarihin faydalarını anlatırken kendinden önceki tarihçilerden de alıntı yaparak tarihçiye ve topluma yol gösterici niteliği olan yedi tane fayda saymaktadır (Şeker, 1997, 33).

Gelibolulu Mustafa Ali'nin tarih yazıcılığı konusunda yaşamından sonra kazandığı önem, büyük ölçüde bu alanda yaptığı katkılara ve ileri sürdüğü sosyal-siyasi eleştirilere dayanmaktadır. Yazar eserlerinde sadece olayları konu almamış, onlara derin bilgi birikimi ve keskin eleştirilerinin yanı sıra saklama gereği duymadığı kişisel kırgınlık duygularını da katmıştır (Fleischer, 2001, 243).

Klasik Dönem'e ait bir diğer eser de Selaniki Mustafa Efendi’nin Tarih-i Selaniki adıyla anılan eseridir. Selaniki, rûzmane biçiminde yazdığı bu eserinde yaşadığı ve gördüğü olayları 
anlatmıştır (Babinger, 2000, 150). Ayrıca Selaniki eserinde, birlikte yaşayıp karakterlerini ve siyasetlerini dile getirdiği Osmanlı devlet adamlarını anlatırken büyük bir titizlik göstermiștir. Eserdeki bilgiler döneminin teşrifatını ve devlet yönetiminde uygulanan hiyerarşiyi ayrıntılı olarak vermesi bakımından da oldukça önemlidir (Refik, 1999, 37).

Tarihi-i Selaniki, Kanuni'nin saltanat yıllarının sonundan III. Mehmet'in saltanatının ortalarına kadar olan 1563-1600 yılları arasındaki olayları içermektedir. Eserde devlet merkezinde cereyan eden olaylar, eyaletlerden merkeze ulaşan çeşitli haberler, arzlar ve şikâyetlerin günü gününe not düşüldüğü görülmektedir. Selaniki’nin eserinde kendi yaşadığı dönem için yaptığ değerlendirmeler ise oldukça önemlidir. Yazar, Kanuni döneminin ihtişam ve rahatı, II. Selim döneminin sakinliği ve III. Murat döneminde aniden durumun değişmesi ve bitmek bilmeyen savaşların etkilerini ayrı ayrı değerlendirmiştir. Selaniki, tarihin bu dönemine 1şık tutarken herhangi bir kronikten yararlanmamış ancak sözlü ve yazılı kimi kaynaklara başvurmuştur (Selaniki Mustafa Efendi, 1999). Yaşadığı dönemin olaylarını kaydeden yazarın tarihi, dönemin bütün gelişmelerini birinci elden aktaran bir kaynak olarak Osmanlı Devleti'nin gelişmesinin zirvesinde olduğu döneminden, aşağıya doğru inişinin şahitliğini yapmaktadır.

\section{Sonuç}

Osmanlı Devleti'nde tarih yazımı zaman zaman sekteye uğramış, kimi zaman da parlak gelişmeler göstererek önemli eserler meydana getirilmiştir. Yükselme öncesi döneme ait eserler oldukça azdır fakat bir o kadar da değerlidir. Bu dönemde yazıldığı bilinen kimi eserler günümüze kadar ulaşamamış ama kendisinden sonra yazılanlara kaynak teşkil etmiştir. Bu bakımdan bu eserler günümüze ulaşamasa da ulaşanlara kaynak olduğu için Osmanlı tarihinin yazımının devamlılığını sağlamışlardır. Bilinen ilk Osmanlı kroniği olan Yahşi Fakih Menakıbnamesi bunların başında gelmektedir.

Yükselme dönemine gelindiğinde Osmanlı tarih yazıcıllğında, devletin güçlü işleyişine paralel olarak, önemli gelişmeler yaşanmıştır. Fatih Sultan Mehmet ve II. Beyazıt'ın padişahlık yaptığı dönemlerde Osmanlı tarih yazıcılığı en önemli eserlerini vermiştir. Bu iki padişahın başlattığı aydınlanma hareketleri ve sosyal düzenlemelerle tarih yazımı konusunda birebir verdiği emirler, bu dönemde birçok değerli eserin meydana gelmesinde etkili olmuştur. 17. yüzyılda tarih yazıcılığının kurumsallaşıp resmiyet kazanmasıyla Osmanlı tarih yazıcılığı saraya bağl1 şekildeki gelişimini sürdürecektir. Fakat Klasik Dönem'de resmi nitelikte olmayan tarih yazıcılığı yine de devlet anlayışı ekseninde gelişmiş, siyasi iradeden bağımsız olmamıştır. Bu durum Osmanlı tarih yazıcılığındaki kendine özgü geleneğin devletin kuruluşundan sonuna kadar devam etmesine neden olmuştur. 


\section{KAYNAKÇA}

Arıkan, Z. (1991). Osmanlı Tarih Anlayışının Evrimi. Tarih ve Sosyoloji Semineri Bildiriler, 77-91. İstanbul: Edebiyat Fakültesi Basımevi.

Aşıkpaşazade. (1992). Aşılkpaşazade Tarihi. Haz. Nihal Atsız. İstanbul: Milli Eğitim Bakanlı̆̆ı Yayınları. Aydın, A. (2002). Osmanlılarda Tarih Yazıcılığı. Türkler, 11, 417-425. Ankara: Yeni Türkiye Yayınları.

Babinger, F. (2000). Osmanlı Tarih Yazarları ve Eserleri. Çev. Coşkun Üçok. Ankara: Kültür Bakanlığı Yayınlari.

Baş, E. (2005). Dil-Tarih İlişkisi Bağlamında Osmanlı Türklerinde Arapça Tarih Yazıcılığı. Ankara Üniversitesi İlahiyat Fakültesi Dergisi, 1, 103-132. Ankara.

Başar, F. (2002). İlk Osmanlı Tarihçileri. Türkler, 11, 409-416. Ankara: Yeni Türkiye Yayınları.

Ersanlı Behar, B. (1996). İktidar ve Tarih Türkiye'de Resmi Tarih Tezinin Oluşumu (1929-1937). İstanbul: Afa Yayınları.

Cengiz, H. E. (1989). Yahşi Fakih. Tarih ve Toplum, Kasım, 71, 39-41. İstanbul.

Çoşkun, İ. (1991). Batı İdeolojilerinin Türk Tarih Anlayışına Yansımaları Üzerine. Tarih ve Sosyoloji Semineri Bildiriler, 43-55, İstanbul: Edebiyat Fakültesi Basımevi.

Enverî. (2003). Düstürname-i Enverî Osmanlı Tarihi Klsmı (1299-1466). Haz. Necdet Öztürk. İstanbul: Kitabevi Yayınları.

Fleischer, C. H. (2001). Tarihçi Mustafa Ali Bir Osmanlı Aydın ve Bürokratı. Çev. Ayla Ortaç. İstanbul: Tarih Vakfi Yurt Yayınları.

Hoca Sadettin Efendi. (1992). Tacü’t-Tevarih. I. Haz. İsmet Parmaksızoğlu. Ankara: Kültür Bakanlığı Yayınları.

İbn-i Kemal. (1970). Tevârih-i Âl-i Osman. I. Haz. Şerafettin Turan. Ankara: Türk Tarih Kurumu Yayınları.

İnalcık, H. (1990). Osmanlı Toplum Yapısının Evrimi. Çev. Mehmet Özden, \& Fahri Unan, Türkiye Günlüğ̈̈, Yaz, 11, 30-41. Ankara: Cedit Yayınları.

İsen, M. (1988). Gelibolulu Mustafa Ali. Ankara: Kültür ve Turizm Bakanlığı Yayınları.

Kemal Paşazade. (1996). Tevârih-i Âl-i Osman (I-II-X. Defterler). Haz. Şerafettin Severcan. Ankara: Türk Tarih Kurumu Yayınları.

Lüfi Paşa. (1341). Tevârih-i Al-i Osman. İstanbul: Matbaa-yı Âmire.

Neşrî, M. (2008). Cihannüma [Osmanlı Tarihi (1288-1485)]. Haz. Necdet Öztürk. İstanbul: Çamlıca Yayınları.

Neşrî, M. (1983). Neşrî Tarihi. I. Haz. Mehmet Altay Köymen. Ankara: Kültür ve Turizm Bakanlığ1 Yayınları.

Ortaylı, İ. (2000). Menkıbe, Osmanlı Devleti’nin Kuruluşu Efsaneler ve Gerçekler. Ankara: İmge Yayınları.

Özcan, A. (2003). Fatih Devri Tarih Yazıcılığı ve Literatürü. Erciyes Üniversitesi Sosyal Bilimler Enstitüsü Dergisi, 14, 2033/1, 55-62. Kayseri.

Refik, A. (1999). Osmanlı Alimleri ve Sanatkârları. Haz. Dursun Dilek. İstanbul: Timaş Yayınları.

Selânikî Mustafa Efendi. (1999). Tarih-i Selânikî. I. Haz. Mehmet İpşirli. Ankara: Türk Tarih Kurumu Yayınları.

Sencer, M. (2002). Osmanlılarda Din ve Devlet. İstanbul: Toplumsal Dönüşüm Yayınları.

Şeker, M. (1997). Gelibolulu Mustafa Ali ve Mevâ'idü’n-nefais fî-Kavâ'ıdü'l-mecâlis. Ankara: Türk Tarih Kurumu Yayınları.

Tekindağ, Ş. (1977). Tursun Bey. Íslam Ansiklopedisi, 12/2, 122-123. İstanbul: Milli Eğitim Bakanlığ Yayınları.

Tekindağ, Ş. (1971). Osmanlı Tarih Yazıcılığı. Belleten, Ekim, XXXV, 655-663. Ankara: Türk Tarih Kurumu Yayınları.

Timur, T. (1994). Osmanlı Kimliği. İstanbul: Hil Yayınları.

Tursun Bey. (1977). Tarih-i Ebu'l-Feth. Haz. A. Mertol Tulum. İstanbul: İstanbul Fetih Cemiyeti Yayınları. Uğur, A. (1991). İdris-i Bitlisî ve Şükr-i Bitlisî. Kayseri: Erciyes Üniversitesi Yayınları.

Yurdaydın, H. G. (2002). Düşünce ve Bilim Tarihi (1300-1600). Türkiye Tarihi, II. Ed. Sina Akşin. İstanbul, 207-271, Cem Yayınlar1. 